\title{
Analgesic and neuromotor effects of two extracts of Zanthoxylum rhoifolium (Rutaceae) in the Swiss albino mouse (Mus musculus)
}

Efectos analgésicos y neuromotores de dos extractos de Zanthoxylum rhoifolium (Rutaceae) en el ratón albino suizo (Mus musculus)

\author{
Melany VILLEGAS-VALENCIA BSc ${ }^{1 \mathbb{D}}$, Libardo A. GONZALEZ-REYES BSc ${ }^{1,2 \mathbb{D}}$, Angelica GARCÍA PhD ${ }^{1 \mathbb{0}}$, \\ Helberg ASENCIO-SANTOFIMIO PhD ${ }^{1 \mathbb{D}}$, Jose O. GUTIERREZ-MONTES $\mathrm{MSc}^{2 \mathbb{D}}$ \& \\ Silverio GARZON-GAVIRIA, $\mathrm{MSc}^{1 \mathbb{1}}$
}

Received: 24 Jun 2019 Approved: 8 december 2020

\begin{abstract}
BACKGROUND: Colombia has a high diversity of medicinal plants, including Tachuelo (Zanthoxylum rhoifolium), a tree belonging to the family Rutaceae, which has been attributed an analgesic use by communities of the Colombian southwest. Nevertheless, this species has been scarce studied in Colombia. The studies have been limited to the isolation of compounds with antifungal and insecticide activity, using the leaves, branches, and bark of the plant in aqueous, and organic extracts. Neither pharmacological tests have been carried out, nor the analgesic and neuromotor activity have been tested from preparations with this plant's fruits. OBJECTIVES: To evaluate the analgesic and neuromotor effect of the aqueous and hexane extract of the fruits of $Z$. rhoifolium. METHODS: As there were no preliminary reports of this study, the first observation was made through Irwin's test. The formalin and the rotarod test were performed to determine the analgesic and motor coordination effects, respectively. RESULTS: All the evaluated treatments demonstrated to generate analgesia, anesthesia, passivity, reduction in the alarm reaction, and have antinociceptive activity in the formalin test; while only the high dose of the nonpolar extract generated a deficit in the motor performance of the rodents in the rotarod test. CONCLUSIONS: the antinociceptive effect of the aqueous and hexane extracts of this species' fruits was demonstrated. The hexane extract generated a neuromotor effect, which validates the ethnobotanical reports on $Z$. rhoifolium fruits.
\end{abstract}

Key words: Zanthoxylum rhoifolium; neuromotor effect; analgesic effect; rotarod test; formalin test.

\section{RESUMEN}

ANTECEDENTES: Colombia tiene una alta diversidad de plantas medicinales, incluyendo al Tachuelo (Zanthoxylum rhoifolium), un árbol de la familia Rutaceae al que se le ha atribuido un potencial analgésico debido al uso por parte de las comunidades del Suroccidente Colombiano. Sin embargo, esta especie ha sido poco estudiada en Colombia, limitándose al aislamiento de compuestos con actividad antifúngica e insecticida, empleando las hojas, ramas y corteza de la planta en extractos acuosos y orgánicos;

Grupo de Investigación en Ciencias Básicas y Clínicas de la Salud, Pontificia Universidad Javeriana, Cali, Colombia.

Grupo de Investigación Farmacología Univalle, Universidad del Valle, Cali, Colombia.

Author to whom correspondence should be directed: Melany Villegas Valencia: mvillegas80@javerianacali.edu.co, Silverio Garzón Gaviria: silveriog@javerianacali.edu.co, Libardo Andrés González Reyes: libardo.gonzalez@correounivalle.edu.co 
sin embargo, no se han realizado ensayos farmacológicos ni se han probado la actividad analgésica y neuromotora a partir de preparaciones con los frutos de esta planta. OBJETIVOS: Evaluar el efecto analgésico y neuromotor del extracto acuoso y en hexano de los frutos de $Z$. rhoifolium. MÉTODOS: Al no haber reportes preliminares de este estudio, se realizó la primera observación mediante el test de Irwin. Para determinar el efecto analgésico y neuromotor se realizó el test de formalina y el test de rotarod, respectivamente. RESULTADOS: Todos los tratamientos evaluados demostraron generar analgesia, anestesia, pasividad, reducción en la reacción de alarma, tener actividad antinociceptiva en el test de formalina, mientras que solo la dosis alta del extracto apolar generó un déficit en el rendimiento motor de los roedores en el test de rotarod. CONCLUSIONES: Se demostró el efecto antinociceptivo del extracto acuoso y en hexano de los frutos de esta especie y el efecto neuromotor generado por el extracto en hexano, validando los reportes etnobotánicos sobre los frutos de Z. rhoifolium.

Palabras clave: Zanthoxylum rhoifolium; efecto neuromotor; efecto analgésico; test de rotarod; test de formalina.

\section{INTRODUCTION}

Pain is a sensory and unpleasant experience of the organisms when facing a nociceptive agent's action. A great variety of analgesics have been developed for pain treatment; however, these antinociceptives can generate effects on the performance of motor coordination and voluntary muscle movement $(1,2)$. A therapeutic alternative could be the use of medicinal plant extracts, which generate positive effects for pain treatment, reducing the development of side effects (3).

The genus Zanthoxylum (Rutaceae) has been of great interest for phytopharmacological studies, and comprises more than 200 trees and shrubs species with a pantropical distribution (4). In Colombia, 21 species of this genus have been registered in almost $75 \%$ of the country's departments, and a wide variety of secondary metabolites with biological activity have been described $(5,6)$. Throughout history, the extensive use of medicinal plants to relieve nociceptive pain includes Zanthoxylum rhoifolium. This species is commonly known as "Tachuelo", a tree found in South America, mainly in the humid tropical forests of the Atlantic Coast of Brazil (7). Infusions or boiling beverages of roots or barks from $Z$. rhoifolium are widely used as a tonic, antipyretic, anti-inflammatory, or antimicrobial (8). The bark is used in Brazilian traditional medicine in infusions or teas as an analgesic agent (against ear pain and irreversible pulpitis), antispasmodic, diuretic, and a muscle relaxant $(9,10,11,12)$. Additionally, the antinociceptive action of $Z$. rhoifolium bark ethanolic extract $(7,8,13)$ has been demonstrated by the use of pharmacological tests in bio-models subjected to chemical nociception. Several studies have also been conducted regarding the study of antinociceptive, analgesic, anti-inflammatory, and neuromotor effects with nonpolar and polar extracts using leaves, bark, branches, and roots of the plant; however, the fruits of $Z$. rhoifolium have not been used to conduct pharmacological studies. Additionally, the communities use the infusions in water to prepare their drinks. In this way, abounding uses of this plant's extracts have been reported, but no studies have been carried out with the hexane fraction (non-polar extract) and the aqueous phase (polar extract) using this species' fruits.

As there are no phytochemical and pharmacological reports on the effects of the extracts in the hexane and aqueous phases with the fruits of Z. rhoifolium, it is necessary to carry out an experimental test evaluating those extracts, using Irwin's Test. This test allows for studying the effect of drugs or natural products in murine bio-models, in shorts (1 hour) or prolonged (24-48 hours) times. The aim is to register possible changes in the central nervous system, somatic, urinary, digestive, respiratory, circulatory, and behavior alteration of the animal, in a general review, and later deepen the alterations found. Additionally, different pharmacological tests allow the evaluation of the analgesic effect of some substance. One of the most effective is the formalin test. Also, to carry out studies with compounds that can have a neuromotor effect, the rotarod test is suggested, which evaluates the alteration of locomotor performance in rodents $(5,14,15,16)$.

Considering the little research done on medicinal plants in Colombia, the scarce ethnobotanical reports on the effects of $Z$. rhoifolium extracts, and the lack of research on this plant's fruits, the present work aimed to 
evaluate the analgesic and neuromotor activity of the whole extract in both, hexane and aqueous phases, obtained from $Z$. rhoifolium fruits and using three different doses for each extract $(125,250$ and $500 \mathrm{mg} / \mathrm{kg})$ on the biomodel Mus musculus.

\section{MATERIALS AND METHODS}

\section{Plant material and storage}

Fruits of $Z$. rhoifolium were collected in January 2017 at Cali, Colombia (3¹9'58.00”N, $76^{\circ} 32^{\prime} 80.40^{\prime} \mathrm{W}, 1070.4$ MAMSL) under the permission of the Biology program of Universidad del Valle for the collection of wild species for scientific research purposes. The plant material collected (2280 g wet weight) was mainly ripe fruits. Those were washed with sodium hypochlorite $2 \%$ in distilled water. The plant material was dried at $70^{\circ} \mathrm{C}$ for five days and then stored at $-80^{\circ} \mathrm{C}$ in liquid nitrogen (14). The material was kept at the Cellular Physiology Laboratory of Universidad del Valle.

\section{Preparation of phytochemical extracts}

The fruits of $Z$. rhoifolium were pulverized with a mortar. $600 \mathrm{~g}$ of the pulverized dry material were used to conduct the phytochemical extraction. This plant material was distributed in equal proportions to make the nonpolar and the aqueous extract. The material corresponding to the nonpolar extract ( $300 \mathrm{~g}$ ) was mixed with $2 \mathrm{~L}$ of analytical methanol, and then $500 \mathrm{~mL}$ of $n$-hexane were added for its partitioning. The resulting solution was added to a separating funnel that divided both methanolic and hexane phases differentially. The separation funnel was agitated and wrapped with aluminum and allowed to stand for 3 days. Subsequently, the phase of interest, the hexane phase, was filtered with a $0.22 \mu \mathrm{m}$ Millipore microfilter.

The other $300 \mathrm{~g}$ of dry material were macerated in $2 \mathrm{~L}$ of ultra-pure water at $27^{\circ} \mathrm{C}$ for 3 days to prepare the aqueous extract. The obtained solution was filtered with a $0.22 \mu \mathrm{m}$ Millipore microfilter. Both filtered samples were concentrated separately in a rota-evaporator under reduced pressure at $50^{\circ}$ $\mathrm{C}$ until the volume was reduced to $10 \mathrm{~mL}$. The extract obtained was added to Eppendorf tubes and later placed in the SpeedVac Eppendorf, where the remaining organic solvent was removed.

\section{Solutions Preparation}

The extracts were dissolved in the vehicle solution (saline solution (0.9\%), Tween 80 and 96\% ethanol (86: 12: 2)), which was also the negative control. Three doses of $Z$. rhoifolium extract were prepared for the hexane and aqueous phase: $125 \mathrm{mg}$ / kg (low dose), $250 \mathrm{mg} / \mathrm{kg}$ (medium dose) and 500 $\mathrm{mg} / \mathrm{kg}$ (high dose) (17). Morphine Hydrochloride $(5 \mathrm{mg} / \mathrm{kg}$, dissolved in saline solution $(0.9 \%))$ was employed as a reference opioid analgesic (positive control) (17). Diclofenac was used as a positive control for a non-steroidal anti-inflammatory drug (NSAID), which was diluted in $0.9 \%$ saline to obtain a $30 \mathrm{mg} / \mathrm{kg}$ dose. Each time the substances were mixed, the Eppendorf tubes were placed in a Thermolyne Vortex Stirrer for 2 minutes, followed by an ultrasonic bath during the same period to facilitate the dissolution of the compounds.

\section{Animals}

The current project was submitted to the Animal Ethics Committee of the Universidad del Valle. It was approved through the guarantee $\mathrm{N}^{\circ}$ 023-2015, based on good laboratory practices in scientific research with bio-models. The Swiss albino mice (Mus musculus, 25-35 g) were used to evaluate the analgesic and neuromotor effect of the hexane extract of the fruit of $Z$. rhoifolium. The rodents were acquired from the bioterium of the University del Valle (Cali, Colombia), where the controlled conditions before experimentation were water and food ad libitum, $12 \mathrm{~h}$ light and $12 \mathrm{~h}$ darkness, and $24 \pm 2^{\circ} \mathrm{C} .28,36$, and 36 mice were used to perform the Irwin, formalin, and rotarod tests, respectively. The animals and intensities of noxious stimuli used were the minima necessary to demonstrate the extract's effects.

\section{Irwin Test}

Since there were no preliminary reports on the effects of the aqueous and hexane extract of $Z$. rhoifolium fruits, the Irwin Test was performed. The treatments used were three doses of the aqueous extract, three doses of the hexane extract, and the vehicle solution as the negative control. Four mice were randomly selected for each one of the groups, and each one intraperitoneal injected (IP) with the respective treatment.

The following parameters were examined if they were altered one hour after the treatment injection: 
central nervous system exciters, central nervous system depressors, eye effects, general behavioral effects, and subjective effects.

\section{Antinociceptive essay: formalin test}

We used 36 individuals in 9 independent groups (four individuals per group). Each group corresponded to a different treatment (low dose, medium dose, and high dose for aqueous and hexane extracts, negative (vehicle) and positive controls (morphine and diclofenac) (19). The mice were injected with the corresponding treatment intraperitoneally. 15 minutes after injection, $20 \mu \mathrm{L}$ of $2.5 \%$ formalin were subcutaneously administered in the right hind paw sub-plantar space. Mice were observed from 0 to 5 min (early phase) and 20 to $25 \mathrm{~min}$ (late phase). The nociception score was determined by the time the animal spent licking the injected limb during the observation time. Besides, the pain inhibition percentage was calculated by comparing the different doses of the extract concerning the vehicle and using the following equation:

Equation 1: (average vehicle - average treatment / average vehicle) $\star 100 \%$

\section{Motor coordination: rotarod test}

The rotarod test allows for the evaluation of the possible nonspecific muscle-relaxant or sedative effects of the extract. Nine-different treatments were used: low dose, medium dose, and high dose for aqueous and hexane extract, negative and positive control (morphine and diclofenac). The nine treatments were administered intraperitoneally, and 15 minutes later, the animals were placed in the rotation bar. Two tests were performed per mouse; in the first test, the bar rotated at speed with constant acceleration, starting at $4 \mathrm{rpm}$, and gradually increased until reaching 20 rpm in a maximum time (120 seconds) (20). In the second test, the bar rotated at a constant speed of $12 \mathrm{rpm}$ for 120 seconds. The rodents were trained for three days before the experiment until they could successfully reach the test values (speed with acceleration from 4 to $22 \mathrm{rpm}$ for 120 seconds; or constant speed of $12 \mathrm{rpm}$ for 120 seconds) (14). The results were expressed as the rpm and time (s) in which the animals fell off the bar, considering $20 \mathrm{rpm}$ and 120 seconds as the maximum value in each test, respectively.

\section{Statistical analysis}

The statistical software of free distribution $\mathrm{R}$ 3.2.2 was implemented. Qualitative data is validated, applying the Chi-square tests corrected from Yate and Fisher. The statistical analyzes were performed by one-way ANOVA to compare the differences between the variables (persistence in the rotarod bar -rpm and s- and licking time -s-) followed by Tukey multiple comparison tests. The differences were considered significant when $\mathrm{p}<0.05$.

\section{RESULTS AND DISCUSSION}

After preparing the extracts of the fruits of $Z$. rhoifolium, the yield of the extraction process with n-hexane was $8.4 \%$, and with water was $3 \%$.

\section{Irwin Test}

The control group that was only supplied with the vehicle did not show alterations in the 34 parameters evaluated. After one hour of treatment injections, both the aqueous and the hexane extract presented paralysis in the posterior extremities, analgesia, anesthesia, inhibition in the alarm reaction, respiratory frequency reduction, passivity, and fear. Significant differences were found between the doses of both extracts and the control for all 7 variables that generated response $(p<0.05)$. There were no differences between the medium and high dose of the aqueous extract $(p=0.194)$. For the hexane extract, there were significant differences among all the doses, where the high dose $(500 \mathrm{mg} / \mathrm{kg})$ presented the most notorious manifestations in comparison with the other doses $(\mathrm{p}<0.05)$.

\section{Extract effect on the formalin test.}

The highest percentage of inhibition registered in the early phase was for the high dose of the hexane extract, followed by the same extract's medium-dose. In the first-mentioned case, the percentage of inhibition is higher than morphine and diclofenac, and in the second case, it is higher than diclofenac (Table 1). Similarly, in the late phase, the same percentage of inhibition (100\%) was observed for the three doses of hexane extract, morphine, and diclofenac. This represents a total reduction in the licking time during this period. Consequently, there was a considerable reduction in the licking time when using any of the extract doses regarding the vehicle (Table 1). 
Table 1. Licking time (s) and percentage of inhibition for the different treatments used in the formalin test in both phases. The licking time data are presented with the mean and the standard deviation (mean \pm S.E.M) for 4 individuals in each treatment.

\begin{tabular}{lcccc}
\hline & \multicolumn{2}{c}{ Early phase (0-5 m) } & \multicolumn{2}{c}{ Late phase (20-25 m) } \\
\hline \multicolumn{1}{c}{ Treatment } & Licking time (s) & Inhibition (\%) & Licking time (s) & Inhibition (\%) \\
\hline Vehicle & $67.9 \pm 3.2$ & - & $55.6 \pm 4.3$ & - \\
Morphine & $4.8 \pm 3.9$ & 93 & 0 & 100 \\
Diclofenac & $8.1 \pm 0.6$ & 88 & 0 & 100 \\
Aqueous $125 \mathrm{mg} / \mathrm{kg}$ & $39.1 \pm 0.7$ & 42.5 & $27.0 \pm 1.4$ & 51.5 \\
Aqueous $250 \mathrm{mg} / \mathrm{kg}$ & $20.0 \pm 2.9$ & 70.5 & $10.2 \pm 0.7$ & 81.6 \\
Aqueous $500 \mathrm{mg} / \mathrm{kg}$ & $11.9 \pm 1.4$ & 82.5 & $7.2 \pm 0.9$ & 87.1 \\
Hexane $125 \mathrm{mg} / \mathrm{kg}$ & $21.7 \pm 2.0$ & 68 & 0 & 100 \\
Hexane $250 \mathrm{mg} / \mathrm{kg}$ & $7.5 \pm 2.8$ & 88.9 & 0 & 100 \\
Hexane $500 \mathrm{mg} / \mathrm{kg}$ & $3.5 \pm 1.7$ & 94.8 & 0 & 100 \\
\hline
\end{tabular}

A significant pain reduction response was observed with all three doses during the first (P1) and the second phase (P2) compared to the negative control. Based on the boxplot generated, it can be concluded that there were differences in the median related to the licking times between the treatments used regarding the control (Figure 1). There were significant differences between the different doses of hexane and aqueous extract with the vehicle in both periods when Tukey's multiple comparisons were applied. The results confirm the antinociceptive action of the extract in both phases over the formalin test. Furthermore, it was observed that there were no significant differences between morphine and diclofenac in both periods, and there were no significant differences between the high dose of hexane extract and morphine in both times.

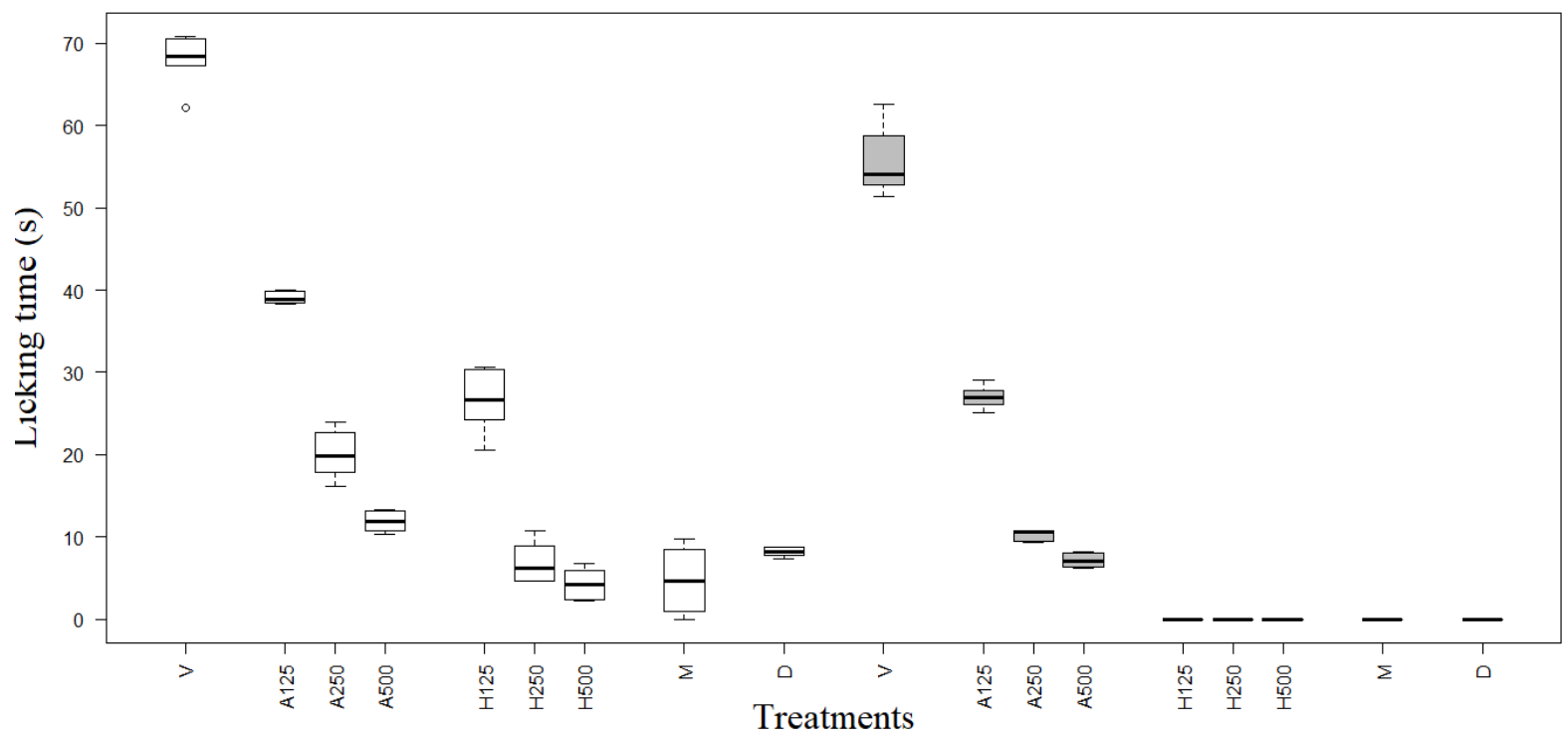

Figure 1. Licking time (s) in early phase and late phase (white and gray boxes, respectively) of the formalin tests, in relation to the different treatments. V: Vehicle, A125: Aqueous extract $125 \mathrm{mg} / \mathrm{kg}$, A250: Aqueous extract 250mg/ kg, A500: Aqueous extract 500mg/kg, H125: Hexane extract 125mg/kg, H250: Hexane extract 250mg/kg, H500: Hexane extract 500mg/kg, M: Morphine, D: Diclofenac. 


\section{Extract effect in the rotarod test}

All three doses of the aqueous extract and the low and medium doses of the hexane extract did not significantly alter motor performance, unlike morphine, diclofenac, and high dose hexane extract. When comparing the treatments with the vehicle, it was observed that the high hexane dose was the one that most altered the motor performance of rodents in both accelerated and constant speed tests (Table 2). With the high dose of hexane extract, there was a decrease in the mice's permanence in the rotarod, except for morphine, which showed an equivalent effect in both tests (Table 2).

Table 2. Treatments effect on motor coordination of rodents subjected to the rotarod test. The data refer to the mean \pm standard deviation of 4 individuals for each treatment.

\begin{tabular}{lcc}
\hline & \multicolumn{2}{c}{ Duration on the rotating bar } \\
\hline \multicolumn{1}{c}{ Treatment } & Revolutions per minute & Seconds \\
\hline Vehicle & $20.0 \pm 0$ & $120.0 \pm 0$ \\
Morphine & $12.0 \pm 2.6$ & $67.25 \pm 2.6$ \\
Diclofenac & $18.2 \pm 1.2$ & $120 \pm 0$ \\
Aqueous $125 \mathrm{mg} / \mathrm{kg}$ & $20.2 \pm 1.2$ & $120.0 \pm 0$ \\
Aqueous $250 \mathrm{mg} / \mathrm{kg}$ & $18.2 \pm 0.81$ & $116.7 \pm 3.8$ \\
Aqueous $500 \mathrm{mg} / \mathrm{kg}$ & $16.2 \pm 2.0$ & $98 \pm 6.5$ \\
Hexane $125 \mathrm{mg} / \mathrm{kg}$ & $18.5 \pm 1.9$ & $120.0 \pm 0$ \\
Hexane $250 \mathrm{mg} / \mathrm{kg}$ & $16.7 \pm 0.95$ & $103.7 \pm 3.3$ \\
Hexane $500 \mathrm{mg} / \mathrm{kg}$ & $14.0 \pm 2.9$ & $61.2 \pm 2.98$ \\
\hline
\end{tabular}

In the rotarod test without acceleration, the treatments whose mice presented greater latency were the low dose of both extracts, followed by aqueous extract's medium dose. This result was almost equivalent to the motor performance observed with the vehicle compared to the same individuals in the accelerated test, whose motor alteration was more evident (Figure 2). Similarly, it was evidenced with Tukey's multiple comparisons for each treatment that there were no significant statistical differences between the low dose of both extracts and the vehicle, for the first acceleration test. Additionally, there were no significant differences between the low dose of both extracts and the medium dose of the aqueous extract in the second test without acceleration. Between the high doses of both extracts, there were significant differences in the second period. In the case of diclofenac, there were no significant differences in both trials regarding the control; therefore, it did not affect the animal's motor performance. In contrast, there were significant differences between the high dose and the vehicle. As expected, morphine $(5 \mathrm{mg} / \mathrm{kg})$ reduced rodent time in the rotary bar in both tests, acting as a central nervous system's repressor. Additionally, when comparing morphine with the high dose of the extract, no statistically significant differences were observed.

a)

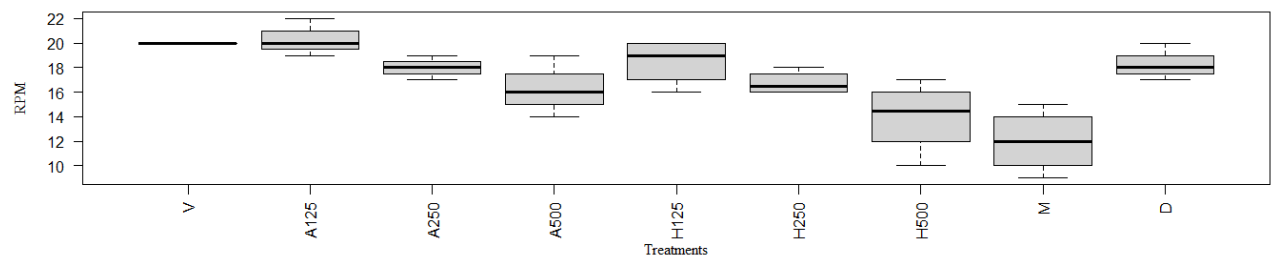

b)

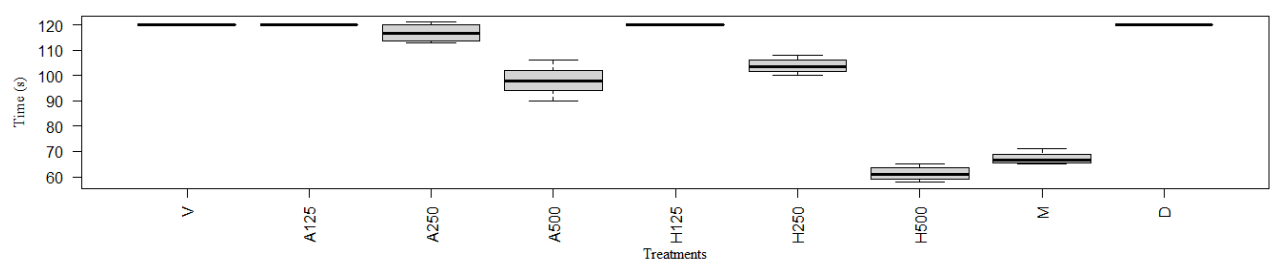

Figure 2. a) Rotarod test with acceleration. Duration of bio-models in revolving bar (rpm) with the different treatments b) Rotarod test without acceleration. Duration of bio-models in revolving bar (sec) with the different treatments. The maximum values of Figures $2 \mathrm{a}$ and $2 \mathrm{~b}$ are represented by $20 \mathrm{rpm}$ and $120 \mathrm{sec}$, respectively, and were equivalent to that the rodents did not fall off the rotating bar during the test period. V: Vehicle, A125: Aqueous extract $125 \mathrm{mg} / \mathrm{kg}$, A250: Aqueous extract $250 \mathrm{mg} / \mathrm{kg}$, A500: Aqueous extract $500 \mathrm{mg} / \mathrm{kg}$, H125: Hexane extract $125 \mathrm{mg} / \mathrm{kg}$, H250: Hexane extract 250mg/kg, H500: Hexane extract 500mg/kg, M: Morphine, D: Diclofenac. 
The Swiss albino mouse evaluated with Irwin's test showed that the vehicle used did not affect the animal's behavior. This result is similar to the formalin test and the rotarod test because it never generated a reduction to the pain signal nor altered the animal's motor activity. The effects observed with the Irwin Test mainly demonstrate the analgesia, anesthesia, passivity, reduction of the alarm reaction, and slight decrease in animal's breathing frequency. These results were related to what was obtained in the formalin and rotarod test. The extracts generated an antinociceptive effect and reduced the animal's mobility, mainly with the nonpolar extract in its highest dose. There may be an inhibition of the central nervous system due to the presence of chemical compounds. Pereira and collaborators (8) carried out a study of the antinociceptive and neuromotor effect of the ethanolic extract of $Z$. rhoifolium but using branches of this species, finding alteration in both nociception and motor performance. This species' fruits may possess chemical compounds such as flavonoids, alkylamides, steroids, and triterpenoids that are causing these effects. Additionally, most of the secondary metabolites found in the species in question are lipophilic, which could easily cross the blood-brain barrier and reach the central nervous system's different cells, explaining the more significant effect generated by the prepared nonpolar extract $(8,21,22,23)$.

The nonpolar extract of $Z$. rhoifolium fruit exhibited significant antinociceptive behavior in both formalin test phases, even at the lowest dose. A similar study in $Z$. riedelianum demonstrated the analgesic properties of the bark's ethanolic extract, inhibiting the activation of the primary afferent fibers in the formalin test (24). Likewise, it has been reported that the ethanolic extract of the bark of $Z$. rhoifolium and its hexane and ethyl acetate fractions produce an antinociceptive response in both formalin test phases, with a pronounced effect in the late phase (inflammatory phase), similar to our results (8). The previous study suggested that the bark extract's analgesic activities can be attributed to the triterpene Lupeol. This compound exhibits a wide variety of biological activities (e.g., anti-inflammatory) and is the main constituent of the hexane fraction (8). However, by isolating the pure Lupeol compound from the bark of Lonchocarpus araripensis (Fabaceae), the compound's antinociceptive action was demonstrated only on the second phase of the pain of the formalin test (25). The above mentioned suggests other metabolites responsible for the analgesic action observed in the extract in the hexane phase of $Z$. rhoifolium in the first phase of the test. Other compounds registered for species of the same genus, which have shown antinociceptive behavior, are rhoifoline A, a benzophenanthrid alkaloid obtained from the ethanolic extract of $Z$. nitidum. Compounds that significantly inhibit the chemical nociception induced by acetic acid and by formalin in both phases (18), as well as the alkylamide hydroxyalpha sanshool, isolated from $Z$. piperitum, which is known to act mainly on the voltage-dependent sodium channels Nav1.7 and Nav1.3 (26).

In the present study, we demonstrated that both extracts high dose, mainly in the hexane phase, generated a motor deficit in the rodents compared with the control group, which remain in the bar throughout the test. The rotarod test showed that morphine compromised the rodents' motor activity, as did the hexane extract in high doses, which suggests that the extract may have the action of muscle relaxant or suppressor of the central nervous system. Other pharmacological agents such as antidepressants, tranquilizers, among others, have produced changes in the rodents' locomotor function (27). Muscle relaxants that act at the central nervous system's level increase interneurons' activity that inhibit the transmission of the efferent neuromuscular signal of the spinal cord. For example, benzodiazepines increase the GABA's effectiveness, a neurotransmitter that plays a role in regulating cerebral excitability (28). Additionally, diclofenac belongs to the nonsteroidal anti-inflammatory drugs (NSAIDs), with analgesic, antiphlogistic and antipyretic properties. It acts mainly by inhibiting the prostaglandins' synthesis by a non-selective blocking of the enzyme cyclooxygenase (COX). It is ideal for analgesia studies at an acute and chronic level because it inhibits both phases of the painful periods. Additionally, it activates the action of nitric oxide pathways and cyclic GMP-dependent potassium channels. These two pathways are involved in the antinociception reactions for both types of drugs. Pain inhibition by morphine and diclofenac were more effective than morphine as an antinociceptive drug by reducing latency times in the plantar test and licking times during the formalin tests. The aforementioned is explained by the fact that mild 
and acute pains respond well to NSAIDs such as diclofenac, but moderate to severe pains require opioid medications $(29,30)$. The low and medium doses of both extracts demonstrated analgesic activity. They did not significantly affect motor performance, which is interesting since an ideal analgesic agent would provide antinociceptive action without compromising motor function (27). However, the use of the high dose of the extract could be convenient in another therapeutic context, such as when required to reduce pain and muscle relaxation. The above would be an important line of research to take into account.

\section{CONCLUSIONS}

The current study demonstrated the pharmacological activity of the aqueous and hexane extract of Zanthoxylum rhoifolium fruits in experimental models of chemical nociception testing three doses for each extract; the effect of the highest dose in the coordination of movement of rodents was also proved. This study demonstrates the communities' ethnobotanical knowledge of the reported analgesic effect of this species' fruits when the preparations are ingested and even when people chew the fruits. It is necessary to continue the studies to find the possible secondary metabolites of the fruits of this species and compare them with those already reported for other parts of the plant or other species of the same genus. The inhibition of the first phase of pain, which was statistically significant, could be due to the compound's inhibitory action at the subcutaneous lesion level, the dorsal root ganglion, or in specific central nervous system regions where neurotransmitters are manifested for the pain. On the other hand, the complete decrease in the responses associated with pain in the second phase, and the decrease in inflammation, suggest that the extract has anti-inflammatory and peripheral antinociceptive effects. This gives value to traditional Colombian medicine's ancestral knowledge and promotes the protection and exploration of plant biodiversity as a reservoir of therapeutic compounds.

\section{CONFLICTS OF INTEREST:}

There is no conflict of interest in the development of the research and manuscript writing.

\section{ACKNOWLEDGMENTS}

The Universidad del Valle is thanked for funding the research project. The participation of the research group in Basic and Clinical Health Sciences of the Pontificia Universidad Javeriana and the Univalle Pharmacology Group is highlighted for the recommendations given for the construction and development of the project.

\section{AUTHOR'S CONTRIBUTIONS}

Melany Villegas Valencia: Problem statement, development of undergraduate thesis within the framework of this research, development of experiments and writing of the article.

Libardo Andrés González Reyes: Problem statement, development of experiments, analysis of results, review and writing of the article.

Angelica García: Direction of graduate thesis, review of the article.

Helberg Asencio Santofimio: Review of results analysis and final document.

Jose Oscar Gutiérrez Montes: Analysis of results and review of the manuscript.

Silverio Garzón Gaviria: Development of the research problem, conduct of experiments, analysis of results and review of final document.

\section{REFERENCES}

1. Parimelazhagan, T. Pharmacological Assays of Plant-Based Natural Products [Internet]. India: Springer; 2016 [cited 2020 Nov 20]. 188 p. Available from: https://www.springer.com/ gp/book/9783319268101 DOI: https://doi.org/10.1007/978-3319-26811-8

2. Quintero GC, Erzurumlu RS, Vaccarino AL. Evaluation of morphine analgesia and motor coordination in mice following cortex specific knockout of the N-methyl-D-aspartate NR1subunit. Neuroscience Letters. 2008; 437(1): 55-58. DOI: https://doi.org/10.1016/j.neulet.2008.03.077

3. Cregg R, Russo G, Gubbay A, Branford R, Sato H Pharmacogenetics of analgesic drugs. British Journal of Pain. 2008; 7(4): 189-208. DOI: https://doi. org $/ 10.1177 / 2049463713507439$

4. British encyclopedia. Zanthoxylum plant genus. [Internet]. https://wplaww.britannica.com/plant/Zanthoxylum 2017 (accessed 8 October 2018).

5. Patiño OJ, Prieto JA, Cuca LE. Zanthoxylum genus as potential source of bioactive compounds. Bioac. Comp. Phytomed [Internet]. 2012 Jan [cited 2018 Mar 18]; 10: 195228. Available from: https://www.intechopen.com/books/ bioactive-compounds-in-phytomedicine/zanthoxylum-genusas-potential-source-of-bioactive-compounds

6. Angulo O. AA, Cuca S. LE. Nuevo esterol y otros constituyentes de Zanthoxylum setulosum. Rev. Colomb. Quím [Internet]. 2002 Jul [cited 2018 nov]; 31 (2): 87-92. Available from: https:// revistas.unal.edu.co/index.php/rcolquim/article/view/18038 
7. Freitas FF, Fernandes HB, Piauilino CA, Pereira SS, Carvalho KI, Chaves MH, et al. Gastroprotective activity of Zanthoxylum rhoifolium Lam. In animal models. J. Ethnopharmacol. 2011; 137: 700-708. DOI: https://doi.org/10.1016/j.jep.2011.06.026

8. Pereira SS, Lopes LS, Marques RB, Figueiredo KA, Costa DA, Chaves MH, Almeida FR. Antinociceptive effect of Zanthoxylum rhoifolium Lam. (Rutaceae) in models of acute pain in rodents. J. Ethnopharmacol. 2010; 129: 227-231. DOI: https://doi. org/10.1016/j.jep.2010.03.009

9. Da Silva SL, Figueiredo PM, Yano T. Antibacterial and antifungal activities of volatile oils from Zanthoxylum Rhoifolium leaves. Pharm. Bio. 2006; 44(9): 657-659. DOI: https://doi. org/10.1080/13880200601006871

10. Da Silva SL, Figueiredo PM, Yano T. Chemotherapeutic potential of the volatile oils from Zanthoxylum rhoifolium Lam. leaves. Eur. J. Pharmacol. 2007; 576: 180-188. DOI: https://doi. org/10.1016/j.ejphar.2007.07.065

11. Da Silva SL, Figueiredo PM, Yano T. Cytotoxic evaluation of essential oil from Zanthoxylum rhoifolium Lam. Leaves. Acta Amazon. 2007; 37(2): 281-286. DOI: https://doi.org/10.1590/ S0044-59672007000200015

12. Ortega EH. Usos tradicionales de las plantas de la Orinoquia colombiana. Rev. Univ. Cien. Sal. [Internet]. 2015 Jan [cited 2019 Jan 23]; 21: 16-28. Available from: https://revistas.ugca. edu.co/index.php/ugciencia/article/view/419

13. Neto B, Leitao J, Oliveira L, Santos S, Carneiro S, Rodrigues $\mathrm{K}$, et al. Inhibitory effects of Zanthoxylum rhoifolium Lam. (Rutaceae) against the infection and infectivity of macrophages by Leishmania amazonensis. An. Braz. Acad. Sci. 2016; 88(4): 1-11. DOI: https://doi.org/10.1590/0001-3765201620150131

14. Bhadoriya U, Yadav A, Aggarwal N, et al. Hypnotic effect of essential oil and methanolic extract of fruits of Zanthoxylum budrunga W. International Journal of Pharmtech Research. 2009; 1(4): 1494-1498.

15. Mathiasen, J. R., \& Moser, V. C. The Irwin Test and Functional Observational Battery (FOB) for Assessing the Effects of Compounds on Behavior, Physiology, and Safety Pharmacology in Rodents. Current Protocols in Pharmacology. 2018; 83(1): 43-49. DOI: https://doi.org/10.1002/cpph.43

16. Roux S, Sablé E, Porsolt RD. Primary observation (Irwin) test in rodents for assessing acute toxicity of a test agent and its effects on behavior and physiological function. Current Protocols in Pharmacology. 2005; 10(10): 10-23. DOI: https:// doi.org/10.1002/0471141755.ph1010s27

17. LJ. Cseke, A. Kirakosyan, PB. Kaufman, SL. Warber, JA. Duke, HL. Brielmann. Natural Products from Plants. Boca Raton, Estados Unidos: CRC Press; 2006. 569 p.

18. Hu J, Shi X, Mao X, Chen J, Zhu L, Zhao Q. Antinociceptive activity of Rhoifoline A from the ethanol extract of Zanthoxylum nitidum in mice. J. Ethnopharmacol. 2013; 150: 828-834. DOI: https://doi.org/10.1016/j.jep.2013.04.035
19. Tjolsen A, Berge O, Hunskaar S, Rosland JH, Hole K. The formalin test: and evaluation of the method. Pain. 1992; 51: 5-17. DOI: https://doi.org/10.1016/0304-3959(92)90003-t

20. Deacon R. Measuring motor coordination in mice. J. Vis. Exp. 2013; 75: 1-8. DOI: https://doi.org/10.3791/2609

21. Lima JA, Oliveira AS, de Miranda AL, Rezende CM, Pinto AC. Anti-inflammatory and antinociceptive activities of an acid fraction of the seeds of Carpotroche brasiliensis (Raddi) (Flacourtiaceae). Braz. J. Med. Biol. Res. 2005; 38: 1095-1103. DOI: https://doi.org/10.1590/S0100-879X2005000700013

22. Feitosa CM, Freitas RM, Luz NN, Bezerra MZB, Trevisan MTS. Plantas medicinais Brasileiras promissoras para inibição da acetilcolinesterase. Brazilian Journal of Biology. 2011; 71(3): 783-789. DOI: https://doi.org/10.1590/S151969842011000400025

23. Hanrahan JR, Chebib M, Johnston GAR. Flavonoid modulation of GABA A receptors. British Journal of Pharmacology. 2011; 163(2): 234-245. DOI: https://doi.org/10.1111/j.14765381.2011.01228.x

24. Lima LM, Ferreira F, Tavares JC, Kenupp J. Anti-inflammatory and analgesic activities of the ethanolic extracts from Zanthoxylum riedelianum (Rutaceae) leaves and stem bark. J. Pharm. Pharmacol. 2007; 59: 1151-1158. DOI: https://doi. org/10.1211/jpp.59.8.0014

25. Oliveira F, Alves V, Barbosa JM, Guedes JR, Rodrigues LC, Botelho M, Flora C. Antinociceptive effect of lupeol: evidence for a role of cytokines inhibition. Phytother. Res. 2013; 27(10): 1557-1563. DOI: https://doi.org/10.1002/ptr.4902

26. Tsunozaki M, Lennertz R, Vilceanu D, Katta S, Stucky CL, Bautista DM. A 'toothache tree' alkylamide inhibits A $\delta$ mechanonociceptors to alleviate mechanical pain. J. Physiol. 2013; 591(13): 3325-3340. DOI: https://doi.org/10.1113/ jphysiol.2013.252106

27. Cartmell SM, Gelgor L, Mitchell D. A Revised rotarod procedure for measuring the effect of antinociceptive drugs on motor function in the rat. J. Pharmacol. Methods. 1991; 26(2): 149-159. DOI: https://doi.org/10.1016/0160-5402(91)90063-b

28. Lullmann H, Mohr K, Hein L, Bieger D. Color Atlas of Pharmacology. New York, Estados Unidos: Thieme; 2005. $414 \mathrm{p}$.

29. Picazo A, Castañeda-Hernández G, Ortiz MI. Examination of the interaction between peripheral diclofenac and gabapentin on the $5 \%$ formalin test in rats. Life Sciences. 2006; 79(24): 2283-2287. DOI: https://doi.org/10.1016/j.lfs.2006.07.025

30. Schaffler K, Reitmeir P, Gschanes A, Eggenreich U. Comparison of the analgesic effects of a fixed-dose combination of orphenadrine and diclofenac (Neodolpasse ${ }^{\circledR}$ ) with its single active ingredients diclofenac and orphenadrine: A placebocontrolled study using laser-induced somatosensory-evoked potentials fr. Drugs in R and D. 2005; 6(4): 189-199. DOI: https:// doi.org/10.2165/00126839-200506040-00001 